\title{
DEVIR-ELE: O NEUTRO NA LITERATURA
}

\author{
Gabrielle da Silva Forster \\ Vera Lúcia Lenz Vianna da Silva ${ }^{2}$
}

RESUMO: Ao reconhecer que a despersonalização do sujeito na experiência da escrita é para alguns pensadores um aspecto crucial da literatura moderna, o presente trabalho objetiva uma aproximação das propostas de Blanchot, Foucault, Deleuze, Guattari, Barthes e Agamben, com o intuito de observar o caráter transgressivo que figura por trás da passagem do eu ao ele indicada por eles.

PALAVRAS-CHAVE: Literatura moderna; Neutro; Devir.

$\mathrm{N}$ o âmbito de uma reflexão na qual o sujeito se despersonaliza no ato da escritura, Deleuze se coloca observando a literatura como uma passagem, uma travessia que nos faz penetrar por um movimento incessante numa zona de indiscernibilidade e de indiferenciação, composta de devires impessoais, inumanos e até mesmo imperceptíveis, que ultrapassam a fronteira do vivenciado para instaurar uma possibilidade de vida outra, além de todo o pessoal. Como para o filósofo francês "escrever é um caso de devir,

1 Graduada em Letras pela Universidade Federal de Pelotas (UFPEL) e Mestre em História da Literatura pela Universidade Federal do Rio Grande (FURG). Atualmente é Doutoranda em Estudos Literários pela Universidade Federal de Santa Maria (UFSM), trabalhando na elaboração da tese intitulada "Devir revolucionário nos escritos de Caio Fernando Abreu e de Reinaldo Arenas: a Literatura como máquina de guerra”, da qual o presente artigo faz parte. E-mail:babiforster@ig.com.br

2 Doutora em Letras pela Universidade Federal do Rio Grande do Sul (UFRGS). Professora orientadora do Programa de Pós-Graduação em Letras da Universidade Federal de Santa Maria (UFSM). E-mail: lenzvl@gmail.com 
sempre inacabado, sempre em via de fazer-se, e que extravasa qualquer matéria vivível ou vivida. É um processo, ou seja, uma passagem de Vida que atravessa o vivível e o vivido" ${ }^{3}$, o que a literatura traz à tona não pode ser encerrado na existência do escritor, no que viveu, conheceu ou percebeu, mas naquilo que transpóe as fronteiras de suas possibilidades, no que ele escuta nos interstícios da linguagem, "nos desvios femininos, animais, moleculares" ${ }^{4}$ que sua sintaxe pode alcançar. Assim, "escrever não é contar as próprias lembranças, suas viagens, amores e lutos, sonhos e fantasmas" ${ }^{5}$, mas fazer a língua delirar, elevando-se até essa zona fronteiriça onde não há mais nem geral nem pessoal, mas uma singularidade impessoal, capaz de invocar um povo por vir, capaz de ser a voz coletiva de uma coletividade menor. É aí que reside sua potência de fuga, pois:

A saúde como literatura, como escrita, consiste em inventar um povo que falta. Compete à função fabuladora inventar um povo. Não se escreve com as próprias lembranças, a menos que delas se faça a origem ou a destinação coletivas de um povo por vir ainda enterrado em suas traiçóes e renegaçôes ${ }^{6}$.

Este povo que se invoca e que está sempre chegando, errante, sem nunca se instalar, "não é um povo chamado a dominar o mundo. É um povo menor, eternamente menor, tomado num devir revolucionário" 7 . E o que o devir propóe é um movimento incessante, que não vai de uma ponta a outra, mas passa entre, rompendo com a binarização. Por isso, o termo menor não se refere ao discurso das minorias, enquanto conjunto de alteridades: mulheres, negros, homossexuais, judeus, etc, pois "reterritorializamo-nos, ou nos deixamos reterritorializar numa minoria como estado, mas desterri-

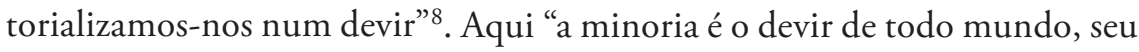

3 DELEUZE, Gilles. Crítica e clínica. São Paulo: Ed. 34, 1997, p. 11.

4 DELEUZE, Gilles. Crítica e clínica. São Paulo: Ed. 34, 1997, p. 12.

5 DELEUZE, Gilles. Crítica e clínica. São Paulo: Ed. 34, 1997, p. 12.

6 DELEUZE, Gilles. Crítica e clínica. São Paulo: Ed. 34, 1997, p. 14.

7 DELEUZE, Gilles. Crítica e clínica. São Paulo: Ed. 34, 1997, p. 15.

8 DELEUZE, Gilles; GUATTARI. Félix. Mil platôs: capitalismo e esquizofrenia. São Paulo: Ed. 34, 1997. Vol. 4, p. 88. 
devir potencial por desviar do modelo" 9 e, portanto, pode e deve passar por esses discursos, desviando-se da constante, que supóe um estado de dominação ${ }^{10}$, mas não pode fixar-se neles. Os filósofos reconhecem nas minorias seu caráter de conjunto, mas o que consideram destas para o seu pensamento são os "cristais de devir, que só valem enquanto detonadores de movimentos incontroláveis e de desterritorialização da média ou da maioria" ${ }^{11}$. Por isso, propóem o termo minoritário, ao invés de minoria, para que possamos entender que:

Há uma figura universal da consciência minoritária, como devir de todo o mundo, e é esse devir que é criação. Não é adquirindo a maioria que se o alcança. Essa figura é precisamente a variação contínua, como uma amplitude que não cessa de transpor, por excesso e por falta, o limiar representativo do padrão majoritário. Erigindo a figura de uma consciência universal minoritária, dirigimo-nos a potências de devir que pertencem a um outro domínio, que náo o do Poder e da Dominação ${ }^{12}$.

Para deixar passar esse devir é preciso conectar vários elementos de minoria e não apenas utilizar dialetos ou características próprias desses grupos considerados menores, pois "criação sintática, estilo, tal é o devir da língua"13, que cada escritor deve encontrar para que a literatura trace na própria língua uma "espécie de língua estrangeira, que não é uma outra língua, nem um dialeto regional redescoberto, mas um devir-outro da língua, uma minoração dessa língua maior, um delírio que a arrasta, uma linha de feitiçaria que foge ao sistema dominante" ${ }^{14}$. Cavar sulcos na própria língua, ser um estrangeiro, um gago na própria língua, de forma a fazê-la delirar, eis a proposta deleuziana,

9 DELEUZE, Gilles; GUATTARI, Félix. Mil platôs: capitalismo e esquizofrenia. São Paulo: Ed. 34, 1995, vol. 2, p. 52.

10 É por isso que os filósofos indicam a impossibilidade de entrarmos num devir-Homem.

11 DELEUZE, Gilles; GUATTARI, Félix. Mil platôs: capitalismo e esquizofrenia. São Paulo: Ed. 34, 1995, vol. 2, p. 53.

12 DELEUZE, Gilles; GUATTARI, Félix. Mil platôs: capitalismo e esquizofrenia. São Paulo: Ed. 34, 1995, vol. 2, p. 53.

13 DELEUZE, Gilles. Crítica e clínica. São Paulo: Ed. 34, 1997, p. 16.

14 DELEUZE, Gilles. Crítica e clínica. São Paulo: Ed. 34, 1997, p. 16. 
que aparece igualmente nas reflexôes formuladas em parceria com Félix Guattari. Para ambos, o fundamental é que cada escritor "tenha seu procedimento de variação, seu cromatismo ampliado, sua louca produção de velocidades"15. Disso resultará o estilo, ou seja, só é possível atingi-lo ao colocar a língua em variação contínua, fazendo "passar o enunciado por todas as variáveis - fonológicas, sintáticas, semânticas, prosódicas — que podem afetá-lo no mais breve instante de tempo"16.

Náo se trata de escrever de forma bela, correta ou grandiloquente, ao contrário, o caso aqui é retorcer a língua, desequilibrá-la, tensionando seus limites sintáticos e gramaticais, para que entoe visôes e audiçôes que não pertencem a um sujeito, nem podem ser encontradas na ordem do dia ou na linguagem corrente porque "não são um assunto privado, mas formam as figuras de uma história e de uma geografia incessantemente reinventadas. É o delírio que as inventa, como processo que arrasta as palavras de um extremo ao outro do universo" ${ }^{17}$. No devir-outro da língua, que é devir-povo, devir-matilha, devir-molécula, devir-devir... o escritor também se torna outro que não mais escritor: músico, pintor, escultor, desenhista, ele é também ouvidor, vidente, "alguém que se torna" ${ }^{18}$, porque "viu na vida algo muito grande, demasiado intolerável também" ${ }^{19}$; uma linha de vida que foge do vivido e do vivível, que ultrapassa seus sentimentos, lembranças e observaçóes. Por isso, "sempre é preciso o estilo - a sintaxe de um escritor, os modos e ritmos de um músico, os traços e as cores de um pintor - para se elevar das percepçóes vividas ao percepto, de afecçóes vividas ao afecto" ${ }^{20}$. É que o vidente, conforme afirma François Zourabichvili:

15 DELEUZE, Gilles; GUATTARI, Félix. Mil platôs: capitalismo e esquizofrenia. São Paulo: Ed. 34, 1995, vol. 2, p. 42.

16 DELEUZE, Gilles; GUATTARI, Félix. Mil platôs: capitalismo e esquizofrenia. São Paulo: Ed. 34, 1995, vol. 2, p. 37.

17 DELEUZE, Gilles. Crítica e clínica. São Paulo: Ed. 34, 1997, p. 9, grifo do autor.

18 DELEUZE, Gilles; GUATTARI, Félix. O que é a filosofia? Rio de Janeiro: Ed. 34, 1992, p. 222.

19 DELEUZE, Gilles; GUATTARI, Félix. O que é a filosofia? Rio de Janeiro: Ed. 34, 1992, p. 222.

20 DELEUZE, Gilles; GUATTARI, Félix. O que é a filosofia? Rio de Janeiro: Ed. 34, 1992, p. 220-221. 
não é aquele que antevê o futuro; ao contrário, ele não vê ou não prevê, para si, nenhum futuro. $\mathrm{O}$ vidente apreende o intolerável em uma situação; ele tem visôes, entendamos, aí, percepçóes em devir ou perceptos, que colocam em xeque as condições usuais da percepção, e que envolvem uma mutação afetiva. A abertura de um novo campo de possíveis está ligada a estas novas condiçôes de percepção: o exprimível de uma situação irrompe, bruscamente ${ }^{21}$.

O que o escritor vê e ouve e faz passar através de seu estilo, de sua sintaxe desviante que coloca a língua em variação contínua para fazê-la vibrar o invisível e o inaudível são potencialidades sempre em movimento, possíveis abertos, que não podem ser fixados, mas que trilham o caminho em devir, para que a linha de fuga possa passar. Nesse trajeto não há captura, pois tudo se torna continuamente outro, desconhecido, estrangeiro. Tudo se agencia de forma a deixar lacunas onde o novo pode nascer, pois "ver essas potencialidades como tais e não atualizadas de maneira determinada: eis o acontecimento que arrasta seu sujeito mutante para um devir-revolucionário" 22 . Assim, atingir perceptos e afectos é alcançar transformaçóes inéditas na arte e pela arte, sustentadas em si mesmas, reais, visto que o "devir não produz outra coisa senão ele próprio. É uma falsa alternativa que nos faz dizer: ou imitamos ou somos. O que é real é o próprio devir, o bloco de devir, e não os termos supostamente fixos pelos quais passaria aquele que se torna" 23 .

Portanto, não perpassamos tal ambiente ou lugar sem que nos tornemos com ele outra coisa, cuja dimensão ultrapassa a percepção vivenciada para traçar uma linha de vida que, demasiado intensa, extravasa todo o vivido e vive por si só. A visão que nos dão os perceptos como "paisagens não humanas da

21 ZOURABICHVILI, François. Deleuze e o possível (sobre o involuntarismo na política). In: ALLIEZ, Eric (org.) Gilles Deleuze: uma vida filosófica. Coordenação da tradução de Ana Lúcia de Oliveira. São Paulo: Ed. 34, 2000, p. 340.

22 ZOURABICHVILI, François. Deleuze e o possível (sobre o involuntarismo na política). In: ALLIEZ, Eric (org.) Gilles Deleuze: uma vida filosófica. Coordenação da tradução de Ana Lúcia de Oliveira. São Paulo: Ed. 34, 2000, p. 341.

23 DELEUZE, Gilles; GUATTARI. Félix. Mil platôs: capitalismo e esquizofrenia. São Paulo: Ed. 34, 1997. Vol. 4, p. 18. 
natureza" 24 , não é a da cidade, a do campo ou a do oceano que conhecemos, por exemplo, nem a daquele que os viu em sua passagem, mas daquilo que a fronteira entre os dois traçou como possibilidade nova na fusão indiscernível dessa zona de vizinhança. Da mesma forma que os afectos não são os sentimentos do escritor que ele projeta no prisma de seus personagens ou "a passagem de um estado vivido a outro, mas o devir não humano do homem" 25 . Não se imita algo, porque devir não é ir dialeticamente de uma ponta a outra, e sim deixar vir à tona o que passa entre, no intermezzo, e que é completamente outro, sendo por isso que pelo viés da perspectiva deleuzo-guattariana "um grande romancista é, antes de tudo, um artista que inventa afectos não conhecidos ou desconhecidos, e os faz vir à luz do dia, como o devir de seus personagens" 26 . Ao recortar o caos, como o faz também a filosofia e a ciência ${ }^{27}$, a arte traça um plano de composição que não concerne a sujeitos, mas a modos de individuação denominados hecceidades, que são

um modo de individuação muito diferente daquele de uma pessoa, uma coisa ou uma substância; uma estação, um inverno, um verão, uma hora, uma data têm uma individualidade perfeita, à qual não falta nada, embora ela não se confunda com a individualidade de uma coisa ou de um sujeito. São hecceidades, no sentido de que tudo aí é relação de movimento e de repouso entre moléculas ou partículas, poder de afetar e de ser afetado ${ }^{28}$.

Aqui, a sensação que se produz é inteiramente nova, variedade entre as variedades, vai além do existente e independe do artista que a criou. É que, de acordo com Deleuze e Guattari, a obra de arte "é um bloco de sensaçóes, isto

${ }^{24}$ DELEUZE, Gilles; GUATTARI, Félix. O que é a filosofia? Rio de Janeiro: Ed. 34, 1992, p. 220.

25 DELEUZE, Gilles; GUATTARI, Félix. O que é a filosofia? Rio de Janeiro: Ed. 34, 1992, p. 224.

26 DELEUZE, Gilles; GUATTARI, Félix. O que é a filosofia? Rio de Janeiro: Ed. 34, 1992, p. 226.

27 Sobre esta questão ver O que é a filosofia?; obra de Deleuze e Guattari já citada.

28 DELEUZE, Gilles; GUATTARI. Félix. Mil platôs: capitalismo e esquizofrenia. São Paulo: Ed. 34, 1997. Vol. 4, p. 47. 
é, um composto de perceptos e afectos" 29 e "as sensaçóes, perceptos e afectos são seres que valem por si mesmos e excedem qualquer vivido" ${ }^{30}$. Por isso, a linha de vida traçada na obra é capaz de potencializar possibilidades outras, que não se deixam apreender em aspectos preexistentes e preconcebidos, podendo, portanto, invocar o "povo que falta", ao qual se referem os filósofos. Esse povo, como povo em devir, é devir-revolucionário que não eclode apenas na arte. Como agenciamento de uma coletividade por vir e não de um sujeito - de um eu encarcerado em seus limites - também arrasta o leitor a essa zona de indiscernibilidade, onde a potência nômade trilha errante: partícula no deserto, desconhecidos que nos habitam, porque o "artista é mostrador de afectos, inventor de afectos, em relação com os perceptos ou as visôes que nos dá. Não é somente em sua obra que ele os cria, ele os dá para nós e nos faz transformar-nos com eles, ele nos apanha no composto"31. Já não é ele - autor; nem nós - leitores, nada de eu, mas metamorfose movente que passa entre.

Quando Deleuze menciona, seja nos trabalhos escritos individualmente ou naqueles produzidos a duas mãos, a potência do impessoal na literatura que repercute na dissolução do sujeito no ato da escrita - sua proposta, embora com particularidades teóricas específicas, estabelece uma das vias de aproximação ao pensamento blanchotiano; fato que o próprio filósofo reconhece ao iluminar várias vezes em seus trabalhos o neutro proposto por Blanchot. Como o referido conceito "não é tanto uma certa modalidade de escritura, é mais uma busca incansável"32, se torna fácil compreender por que, nas reflexôes moventes e transgressoras de ambos os pensadores, a ruptura com o "eu" que envolve o termo é ponto de contato entre suas considerações. É que, tanto para Deleuze quanto para Blanchot, a literatura moderna está sempre por se fazer, fazendo-se de maneira ininterrupta, porque ela é busca/devir e não estado. Ela propóe que se trilhe um caminho sem começo nem fim, no

29 DELEUZE, Gilles; GUATTARI, Félix. O que é a filosofia? Rio de Janeiro: Ed. 34, 1992, p. 213, grifos dos autores.

30 DELEUZE, Gilles; GUATTARI, Félix. O que é a filosofia? Rio de Janeiro: Ed. 34, 1992, p. 213, grifo dos autores.

31 DELEUZE, Gilles; GUATTARI, Félix. O que é a filosofia? Rio de Janeiro: Ed. 34, 1992, p. 227.

32 HOPPENOT, Eric. Escritura e fadiga nas obras de Roland Barthes e Maurice Blanchot. In: QUEIROZ, André; MORAES, Fabiana de; CRUZ, Nina Velasco (orgs). Barthes/ Blanchot: um encontro possivel? Rio de Janeiro: 7 Letras, 2007. p. 91. 
qual se deve entrar rizomaticamente, por todos os lados, para ouvir o murmúrio que se agita no intermezzo das palavras. Para dizer o que não pode ser dito, mas que teima em balbuciar a liberdade do desconhecido sem amarras, aquilo que escapa aos cálculos, o descontínuo no pensamento, a ausência que todos somos. É pelo fato de a literatura estar "antes do lado do informe, ou do inacabamento" ${ }^{33}$ que dentro da perspectiva blanchotiana "o escritor nunca sabe que a obra está realizada. O que ele terminou num livro, recomeçá-lo-á ou destruí-lo-á num outro" ${ }^{34}$, porque no momento em que lançamos os dados, as palavras nos arrastam e o que pretendíamos dizer se dissolve no interminável, ou seja, naquilo que poderíamos seguir dizendo de outras formas, sem nunca poder dizer de uma vez por todas, visto que "escrever é fazer-se eco do que não pode parar de falar" ${ }^{\prime 3}$.

E o que não pode parar de falar para Blanchot também não é - de maneira alguma - o sujeito inclinado à confissão, com suas recordaçôes, vivências, percepçóes e opinióes em torno do mundo, mas aquilo que passa entre a linguagem no momento em que ela está alçada na experiência do fora, lá onde os limites se desfazem e os contornos conhecidos se diluem, onde o desconhecido, o impossível, tem lugar. Como para o referido pensador, "escrever é o interminável e o incessante" 36 , nessa empreitada "o escritor já não pertence ao domínio magistral em que exprimir-se significa exprimir a exatidão e a certeza das coisas e dos valores segundo o sentido de seus limites" 37 .

Aqui, o homem enquanto ser finito atravessa essa fala desértica, infinitamente errante, da qual só se faz eco com a condição de impor-lhe silêncio; o que, de acordo com Blanchot, é o tom da obra, já que este "não é a voz do escritor, mas a intimidade do silêncio que ele impóe à fala" ${ }^{38}$. Nesse sentido, o silêncio não significa calar-se, deixar de dizer, e sim apenas deixar de dizer a partir de nossas demarcaçóes, distanciar-se de si para poder ouvir e, então, recortar esse murmúrio que não cessa, de maneira a deixá-lo falar através da

33 DELEUZE, Gilles. Crítica e clínica. São Paulo: Ed. 34, 1997, p. 11.

34 BLANCHOT, Maurice. O espaço literário. Rio de Janeiro: Rocco, 2011, p. 11.

35 BLANCHOT, Maurice. O espaço literário. Rio de Janeiro: Rocco, 2011, p. 18.

36 BLANCHOT, Maurice. O espaço literário. Rio de Janeiro: Rocco, 2011, p. 17.

37 BLANCHOT, Maurice. O espaço literário. Rio de Janeiro: Rocco, 2011, p. 17.

38 BLANCHOT, Maurice. O espaço literário. Rio de Janeiro: Rocco, 2011, p. 18. 
(des) $\operatorname{costura}^{39}$ que se lhe impõe. Por isso, a postura do escritor é a de uma passividade ativa, na qual ele retira-se de si para dizer o que nunca acaba de ser dito e, portanto, precisa ser atravessado e escutado para dizer, visto que "do 'Eu' apagado [o escritor] conserva a afirmação autoritária, ainda que silenciosa” ${ }^{40}$. É na conexão entre a dissolução do sujeito e seu retirar-se da inerência, mas não da inação, que o pensador francês nos explica o que entende por tom:

Quando numa obra lhe admiramos o tom, sensíveis ao tom como ao que ela tem de mais autêntico, o que queremos designar por isso? Não o estilo, nem o interesse e a qualidade da linguagem mas, precisamente, esse silêncio, essa força viril pela qual aquele que escreve, tendo-se privado de si, tendo renunciado a si, possui nesse apagamento mantido, entretanto, a autoridade de um poder, a decisão de emudecer, para que nesse silêncio adquira forma, coerência e entendimento aquilo que fala sem começo nem fim ${ }^{41}$.

Embora a partir desta citação notemos que, em Blanchot, estilo e tom não coincidem, é possível estabelecer uma linha de contato entre o tom blanchotiano e o estilo, conforme é entendido na perspectiva deleuzo/guattariana. $\mathrm{O}$ que à primeira vista poderia indicar uma discordância entre os dois pensadores (o que neste aspecto não nos parece o caso, sendo por isso que fazemos a ressalva) é apenas uma divergência de traçados própria de cada um, mas que converge num ponto: o fato de tanto o tom quanto o estilo, nas suas acepçóes diferentes e considerando-se suas especificidades de reflexão, indicarem o mergulho do escritor não na interioridade de seu "eu", mas na exterioridade da linguagem. Mesmo que, de um lado, o escritor deva retorcer a língua para deixar vir à tona o invisível e o indizível, e, do outro, o escritor deva calar-se para impor o silêncio - uma espécie de recorte - a essa fala incessante, que é fala do desconhecido, do estrangeiro, em ambos os casos é necessário ultrapassar

39 Uso o termo descostura para indicar a forma como se dá a prega do fora. Esta produz uma curvatura que configura um dentro do fora; um lado coextensivo, uma desdobra como invaginação.

40 BLANCHOT, Maurice. O espaço literário. Rio de Janeiro: Rocco, 2011, p. 19.

41 BLANCHOT, Maurice. O espaço literário. Rio de Janeiro: Rocco, 2011, p. 18. 
os limites da subjetividade para dar lugar ao coletivo impessoal, que é esta fala sem sujeito nem objeto, aquém de todas as dominaçóes, inclusive gramaticais.

Nesse sentido, a escrita como devir e o neutro na escritura se interseccionam na proposta de um trajeto que não vai dialeticamente de um lado ao outro para concluir um entre-lugar sintetizador entre dois termos. Na reflexão de ambos os pensadores, o percurso que advém tanto de seus escritos quanto da compreensão de escrita que eles propóem é o de situar-se no que se ramifica no meio, no espaço liso, desértico, onde o binarismo se dilui porque o terceiro termo já não conclui, mas perambula, tornando-se se outro na "dupla captura”, nem um nem outro: fora dos dois. E, aqui, acreditamos que Barthes e sua reflexão introdutória sobre o Neutro no curso ministrado em 1978 no Collège de France pode esclarecer a relação que pretendemos apontar. No livro homônimo que nos chega destas aulas, o teórico, na esteira de sua semiologia, nos apresenta vinte e três figuras que podem ser vistas como signos que indicam a cintilação do Neutro, deixando emergir, destas, a concepção do termo que pretende mapear, e cujo argumento nos dá de saída, como definição:

Defino o Neutro como aquilo que burla o paradigma, ou melhor, chamo de Neutro tudo o que burla o paradigma. Pois não defino uma palavra; dou nome a uma coisa: reúno sob um nome, que aqui é Neutro. Paradigma é o quê? É a oposição de dois termos virtuais dos quais atualizo um, para falar, para produzir sentido $^{42}$.

Com o intuito de pensar o Neutro, que aqui aparece com maiúscula, já que a proposta é sondá-lo, abrindo-o em vertentes interdisciplinares - enquanto em Blanchot o conceito foge, cruzando-se com outros para alcançar seu sentido -, o referido pensador parte da concepçáo de que "o paradigma é o móbil do sentido; onde há sentido, há paradigma, e onde há paradigma (oposição) há sentido" “3 . Essa condição de escolha que implica consequentemente a rejeição, e que é o fundamento da própria estrutura linguística, reflete a marca de poder que se assenta sob a oposição binária, residindo nisso

42 BARTHES, Roland. O neutro. São Paulo: Martins Fontes, 2003, p. 16-17.

43 BARTHES, Roland. O neutro. São Paulo: Martins Fontes, 2003, p. 17. 
a necessidade de propor outro percurso de pensamento, no qual o neutro tem seu lugar, justamente porque burla a escolha, o paradigma, ao se afirmar como "nem...nem", ou seja, ao indicar o entre sem síntese, que é também o "e...e...e" do devir deleuzo-guattariano, que repercute na individuação sem sujeito denominada hecceidade. Portanto, neutro não significa neutralidade no sentido de passividade, de indiferença; há um desejo de neutro, como assume Barthes, e esse desejo se coloca na esfera da ética, porque “'burlar o paradigma é uma atividade ardente, candente" 44 .

A partir disso, podemos perceber que no neutro blanchotiano a relação sem sujeito é apenas uma das entradas na experiência do fora, que, transitando no descontínuo da continuidade, não quer deixar-se capturar por nenhuma verdade e que, por conseguinte, começa por estremecer a unidade do cogito. Por isso, na perspectiva blanchotiana, "quando escrever é entregar-se ao interminável, o escritor que aceita sustentar-lhe a essência perde o poder de dizer 'Eu' [e] perde então o poder de fazer dizer 'Eu' a outros que não ele" ${ }^{\text {" }}$. E isso porque nesse devir-outro, que implica a passagem da primeira para a terceira pessoa, o "ele" não se refere a outro sujeito da enunciação, encerrado em sua consciência que se distingue da minha, da tua, da de alguém que enuncia, mas à "neutralidade de um 'Ele' sem rosto" 46 , pois “"Ele' sou eu convertido em ninguém, outrem que se torna o outro" ${ }^{47}$ e por isso mesmo também se transforma em Alguém, que é "o que está ainda presente quando não há ninguém" ${ }^{48}$. Manifestação do fora, Alguém, outro, é o neutro, o impessoal, que é voz de todos enquanto voz de nenhum, enquanto fala radicalmente estrangeira, pois, conforme coloca Tatiana Levy:

Quando Blanchot se refere ao outro, não está se referindo ao Uno, ao Mesmo, escondido sob a forma de uma terceira pessoa. $\mathrm{O}$ outro não fala como um $e$, mas tampouco se constitui como objeto [...] Sua relaçấo comigo não é a de sujeito a sujeito, na medida em que a terceira pessoa (o ele) não é uma

44 BARTHES, Roland. O neutro. São Paulo: Martins Fontes, 2003, p. 19, grifo do autor. 
terceira pessoa. O ele é estranho ao eu, colocando em evidência o desconhecido, o vazio que há na relação entre ambos. Essa relação é uma relação neutra, uma relação sem relação, duplamente dissimétrica. A dialética passa longe daquilo que constitui o que Blanchot chama de relação do terceiro tipo e que, mais tarde, Foucault e Deleuze vão retomar. O outro é o outro em sua infinita distância, em seu desconhecimento que não se tornará nunca o idêntico. $\mathrm{O}$ outro é, pois, aquele que não se entrega ao mesmo ${ }^{49}$.

Assim percebemos que ao propor o conceito de neutro, sugerindo a despersonalização do sujeito na vitalidade da escrita, Blanchot não o faz para exaltar a obra como um universo autotélico, com um sentido fechado em si mesmo; pelo contrário, sua intenção é a de propor a abertura em direção ao fora; abertura que sim, se dará na obra, na sua busca, na procura incessante que a palavra empreende, no questionamento inacabado que é o germe de toda questão ${ }^{50}$. Porém na obra enquanto desobra, ou seja, como obra de ruína, transgressora, fora de toda lei, e que, por isso mesmo, não se move em direção ao Livro, mas no caminho de sua destruiçãa ${ }^{51}$, que é deixar a linguagem ir mais além, errante, como palavra outra àquele que escreve e igualmente àquele que a lê, pois "o leitor não quer uma obra escrita por ele; quer justamente uma obra estrangeira em que descubra algo desconhecido, uma realidade diferente, um espírito separado que possa transformá-lo e que ele possa transformar em si" 52 . Portanto, se "os outros não querem ouvir

49 LEVY, Tatiana Salem. A experiência do fora: Blanchot, Foucault e Deleuze. Rio de Janeiro: Civilização Brasileira, 2011, p. 44.

${ }^{50}$ No capítulo intitulado: A questáo mais profunda, incluído no primeiro volume de $A$ conversa infinita, para pensar essa questão interrogante, "interrogação que não interroga, que não quer resposta e parece atrair-nos para a irresponsabilidade e a esquiva de uma fuga tranquila" (2010, p.46), Blanchot coloca que "na simples estrutura gramatical da interrogaçáo, já podemos sentir a abertura da palavra interrogante" (2010, p. 42).

51 ...que não se refere, conforme sugere Blanchot, à ausência de livro que poderia efetuar-se com a disseminaçáo cada vez maior dos meios audiovisuais de leitura, e sim, como ele coloca, à "ordem submetida à unidade" (2010, p.9) que o Livro indica. Por isso, a maiúscula que mantemos no texto.

52 BLANCHOT, Maurice. A parte do fogo. Rio de Janeiro: Rocco, 2011, p. 317. 
suas próprias vozes, mas sim a voz de um outro, uma voz real, profunda, que incomoda como a verdade" 53 , o escritor não pode escrever a partir de si e do que supóe conhecido de si e do mundo, isso seria colocar-se na esfera da identidade, fazer o jogo do uno e do mesmo, confiar na armadilha da certeza. Em contraposição ao discurso naturalizado, deve lançar-se na experiência da linguagem, que em sua busca incessante ensaia um pensamento impossível, sem estreia. É que nesse,

o impossível não está aí para fazer capitular o pensamento, mas para deixá-lo anunciar-se segundo uma outra medida diferente daquela do poder. Que medida seria esta? Talvez precisamente a medida do outro, do outro enquanto outro, e não mais ordenado de acordo com a clareza daquilo que o adéqua ao mesmo ${ }^{54}$.

Por isso, quando a obra se desvela busca em face do desconhecido - termo que na perspectiva blanchotiana não suporta o "ainda", ou seja, qualquer futuro para sua descoberta, nem significa uma sabedoria que poderá ser transmitida - a relação que ela propóe entre a escrita e a leitura deve ser uma relação descontínua, na qual a palavra plural se afirma, desfazendo a ponte segura entre dois para introduzir o terceiro termo, palavra radicalmente outra. É que "a leitura não é uma conversação, ela não discute, não interroga [...] a leitura verdadeira jamais questiona o livro verdadeiro; mas tampouco é submissão ao texto" 55 . O leitor não acrescenta nada ao livro, cujas palavras já estão impressas, nem questiona a veracidade do que se lhe apresenta: faz o pacto, silencia para escutar. No entanto, frente à Obra sempre inacabada que atravessa o recorte, o livro, a obra individual, ele se dispersa na abertura, torna-se anônimo, abre-se para o desconhecido, responde. A exigência de que o escritor se ausente para que a obra e seu murmúrio incessante falem estende-se ao leitor, àquele que faz com que ela se torne obra ao dizer sim à leitura, pois nessa afirmação é preciso negar a si mesmo, tornar-se outro perante a experiência, que, aqui, não produz resultados, mas relação, sempre dissimétrica.

53 BLANCHOT, Maurice. A parte do fogo. Rio de Janeiro: Rocco, 2011, p. 317.

54 BLANCHOT, Maurice. A conversa infinita: a palavra plural. São Paulo: Escuta, 2010, p. 87.

55 BLANCHOT, Maurice. O espaço literário. Rio de Janeiro: Rocco, 2011, p. 211. 
A distância que se impóe é fundamental, pois "só temos relaçôes com o próximo se não nos confundirmos com o próximo, só nos comunicamos plenamente com alguém se possuímos, não o que ele é, mas o que nos separa dele" ${ }^{25}$. Somente reconhecendo no outro a sua irredutibilidade, o seu inapreensível constitutivo (não posso apreendê-lo nem ele próprio pode); só (des) contornando o desconhecimento que o dispersa numa dança vaga em que nos tocamos na distância, sem pedir que ele se torne o que somos porque, passantes, também não passamos de desconhecidos, estrangeiros, errantes, é que a comunicação pode de fato se efetuar. E isso porque aqui ela é ainda o incomunicável, carrega junto sua própria face, o obscuro do indizível, a potência do impossível, outrem que é outro. Entre eu e tu, relação neutra, que nas palavras iluminadoras de Peter Pelbart é

Relação com o estranho, o estrangeiro, a alteridade, com aquilo que irremediavelmente estará fora, do meu espaço, do meu tempo, da minha consciência, do meu eu, da minha palavra, do meu controle. Estará fora do meu mundo, de forma desconhecida, impessoal, na mais próxima distância, na mais ausente das presenças, como aquilo que excede o meu pensar, convulsiona meu sentir, desarma meu agir ${ }^{57}$.

E o que pode ser mais radicalmente outro do que a morte? Pensar a morte é pensar o impossível, ultrapassar o limite de nosso "eu", lançando-se ao abismo onde já não podemos mais estar. É que morrer se move numa fuga perpétua, é sempre depois; depois que nunca chegará, porque, no momento em que se consuma, já não mais somos, ou seja: "nunca se morre agora, morre-se sempre mais tarde, no futuro, um futuro que nunca é atual, que só pode chegar quando tudo estiver consumado, e quando tudo estiver consumado não haverá mais presente, o futuro será de novo passado" 58 . Por isso, a morte é sempre a morte do outro, sempre morte impessoal: "morre-se" e nunca "eu morro"; eu não posso morrer porque quando morro já não morro, já não

56 BLANCHOT, Maurice. A parte do fogo. Rio de Janeiro: Rocco, 2011, p. 244.

57 PÉLBART, Peter Pál. Da clausura do fora ao fora da clausura. São Paulo: Editora Brasiliense, 1989, p. 98.

58 BLANCHOT, Maurice. O espaço literário. Rio de Janeiro: Rocco, 2011, p. 179. 
sou $^{59}$. Nesse sentido, colocar-se de frente a essa impossibilidade, olhá-la com os olhos já putrefatos, escrever com a mão já ausente se torna uma possibilidade de liberdade que o canto configura ao trazer à luz a potência da outra noite, a falta constitutiva, pois tocar o próprio rosto como sombra já diluída é uma espécie de poder que escapa a toda forma de poder, tornando-o o seu "é" sem sentido perante a compreensão do que não é, o reconhecimento do não ser, visto que:

Fazer da morte a minha morte, já não é mais, portanto, atualmente, manter-me eu até na morte, é ampliar esse eu até a morte, expor-me a ela, não mais excluí-la mas incluí-la, olhá-la como minha, lê-la como a minha verdade secreta, o assustador em que reconheço o que sou, quando sou maior do que eu mesmo ou absolutamente grande ${ }^{60}$.

A figura do cadáver que nos dá Blanchot como a imagem da presença-ausente, daquele que embora conhecido por nós e imóvel no caixão - morto - se dispersa suspenso, sem que possamos mais apreendê-lo, sem que consigamos saber onde está o que antes nos era familiar, mas cujos traços conhecidos, agora rígidos, afastam-no de sua antiga existência, aproxima-se de sua visão da palavra, visto que esta carrega a marca da morte, ou seja, "a palavra me dá o que ela significa, mas primeiro o suprime" ${ }^{61}$. Quando nomeio algo, quando torno este qualquer, presente pela palavra, faço-o sob a forma de uma ausência: o gato, a casa, a criança, o eu, o que for, é retirado de seu ser, de sua realidade material, quando se torna tinta, cor no papel. Logo, o cadáver que vemos revela o não ser do ser que conhecíamos; assim como a palavra só nos dá o que enuncia em sua ausência enunciada. No âmbito da reflexão blanchotiana, "quando falo: a morte fala em mim"62:

59 De acordo com Blanchot, a morte é o que "nunca me acontece, de sorte que jamais 'eu morro' mas 'morre-se', morre-se sempre outro que não eu, ao nível da neutralidade, da impessoalidade de um Ele eterno" (2011, p. 263).

60 BLANCHOT, Maurice. O espaço literário. Rio de Janeiro: Rocco, 2011, p. 137.

61 BLANCHOT, Maurice. A parte do fogo. Rio de Janeiro: Rocco, 2011, p. 331.

62 BLANCHOT, Maurice. A parte do fogo. Rio de Janeiro: Rocco, 2011, p. 332. 
Certamente, minha linguagem não mata ninguém. No entanto: quando digo "essa mulher", a morte real é anunciada e já está presente em minha linguagem; minha linguagem quer dizer que essa pessoa que está ali agora pode ser separada dela mesma, subtraída à sua existência e à sua presença e subitamente mergulhada num nada de existência e de presença; minha linguagem significa essencialmente a possibilidade dessa destruição; ela é, a todo momento, uma alusão resoluta a esse acontecimento ${ }^{63}$.

A morte é o que há de mais impessoal a cruzar a própria pessoalidade, o impossível que se torna visível ao homem na compreensão de sua finitude; a passagem que abre as portas ao infinito. Por isso, ela é tão cara nas reflexóes de Blanchot, e não apenas nessas, mas também nas de outros, cujas vozes propóem um novo percurso ao pensamento, de forma que ele ultrapasse os limites de sua possibilidade, transgredindo assim toda lei: a do sujeito como unidade, a do todo como fundamento, a da linguagem como código, a do livro como obra, a do mundo como verdade, a de Deus como pai e modelo. Na relação da literatura com a morte, que cruza constantemente a perspectiva blanchotiana, Foucault, que, na esteira desse pensar, também dá suas contribuiçóes a respeito dos conceitos: fora, neutro; e de suas ideias motores: pensamento do exterior, despersonalização do sujeito, incluindo nessas conexôes o seu "ser da linguagem”, entre tantas outras nuanças, também aqui faz suas consideraçóes.

Em "A linguagem ao infinito" 64 , o referido pensador parte das propostas de Blanchot, objetivando mostrar a imbricação da morte com a fala e, logo, a soberania da linguagem quando - literatura - se afirma como em face ao abismo. De acordo com Foucault, toda a fala é atravessada pela morte, atraída por ela e dita para traí-la, porque "o discurso, como se sabe, tem o poder de deter a flecha já lançada em um recuo do tempo que é seu próprio espaço" ${ }^{65}$. No entanto, nem sempre o espaço aberto pela morte na fala teve o mesmo sentido ou se apresentou sob a mesma forma. No percurso arqueológico

63 BLANCHOT, Maurice. A parte do fogo. Rio de Janeiro: Rocco, 2011, p. 332.

64 (1963).

65 FOUCAULT, Michel. A linguagem ao infinito. In: Estética: literatura e pintura, música e cinema. Ditos e escritos III. Rio de Janeiro: Forense Universitária, 2009. p. 47. 
que impele ao texto, Michel Foucault parte da Odisseia de Homero, onde os deuses ainda falavam e davam os infortúnios aos mortais para que eles contassem o vazio que não cessa de rondar e contra o qual deveriam se defender, mas cujo "infinito manancial", que a fala dos ainda vivos abria, retornava aos deuses, era voz além e não busca escavada no texto. Falar aqui era falar visando à glória, à imortalidade do herói, e por isso "era avançar em direção e contra essa morte que afirma a linguagem" ${ }^{66}$, residindo nisso o fechamento da narrativa, que colocava fora dela, na linguagem dos deuses, "o espelho ao infinito que toda linguagem faz nascer assim que ela se insurge verticalmente contra a morte" 67.

Quando Ulisses escuta sua própria história numa fala atemporal, sente-se outro, está ausente, é vazio passante e sem tempo; vê-se em face ao interminável, ao incessante e ao infinito. No entanto, ele reage a essa reduplicaçáo que o murmúrio abre, esquivando-se. Deixa que essa voz seja a do aedo inspirado pelas musas e passa a narrar sua história para imortalizá-la, fechando-a. Ulisses afasta-se dessa voz, como se afasta do canto das sereias. Nesse sentido, embora aqui, a dobra que se produz delineie "que a morte é, sem dúvida, o mais essencial dos acidentes da linguagem (seu limite e centro)" ${ }^{68}$, a duplicação da narrativa no contato com a morte aparece como um episódio que se coloca para além, na palavra de origem, e por isso só aparece na obra como conteúdo passado. E isso porque, como coloca Foucault:

toda a obra era feita para terminar, para se calar em um silêncio no qual a Palavra infinita iria retomar sua soberania. Na obra a linguagem se protegia da morte por essa palavra invisível, essa palavra de antes e depois de todos os tempos dos quais ela se fazia apenas o reflexo logo encerrado em si mesmo ${ }^{69}$.

66 FOUCAULT, Michel. A linguagem ao infinito. In: Estética: literatura e pintura, música e cinema. Ditos e escritos III. Rio de Janeiro: Forense Universitária, 2009. p. 52.

67 FOUCAULT, Michel. A linguagem ao infinito. In: Estética: literatura e pintura, música e cinema. Ditos e escritos III. Rio de Janeiro: Forense Universitária, 2009. p. 52.

68 FOUCAULT, Michel. A linguagem ao infinito. In: Estética: literatura e pintura, música e cinema. Ditos e escritos III. Rio de Janeiro: Forense Universitária, 2009. p. 49.

69 FOUCAULT, Michel. A linguagem ao infinito. In: Estética: literatura e pintura, música e cinema. Ditos e escritos III. Rio de Janeiro: Forense Universitária, 2009. p. 52. 
Porém, com a retirada dos deuses, que vislumbrou Hölderlin, a linguagem descobre-se no vazio, único espaço para a fala afastar a morte. Enquanto antes o infinito que a morte abria se esparramava duplicado numa voz divina, agora, na ausência dessa palavra, é na linguagem que o incessante se duplica, e inúmeras vezes, para fugir e se sustentar perante a morte. Para Foucault, essa modificação, que se deu no século XVIII, marca o nascimento da literatura, quando a obra de linguagem se torna tal, repetindo em si mesma o canto do infinito, por meio de constantes jogos de espelhos imbricados na auto-representação. De acordo com o teórico, "a aparição simultânea nos últimos anos do século XVIII da obra de Sade e das narrativas de terror marca essa data"70, essa modificaçáo. Não pela inserçấo do mal e da crueldade, mas sim porque são "linguagens que se representam a si mesmas numa cerimônia lenta, meticulosa e prolongada ao infinito [...] são linguagens curiosamente duplas" ${ }^{\text {"11 }}$. Entấo, é nesse período que ele vê o limiar do que chama de literatura, ou seja, "quando aparece uma linguagem que retoma e consome em sua fulguração outra linguagem diferente, fazendo nascer uma figura obscura mas dominadora, na qual atuam a morte, o espelho e o duplo, o ondeado ao infinito das palavras" 72 .

Em "Linguagem e literatura"73, Foucault aponta, na configuração do que denomina literatura ou, mais especificamente, a linguagem literária moderna, dois aspectos: de um lado "a palavra de transgressão, de outro, o que chamaria de repetiçáo contínua da biblioteca"74 75 . É sobre este segundo que fecha o ensaio com o qual vínhamos dialogando até entâo. Após mencionar Sade e os romances de terror, ilumina Borges e seu conto "A torre de Babel", para

${ }_{70}$ FOUCAULT, Michel. A linguagem ao infinito. In: Estética: literatura e pintura, música e cinema. Ditos e escritos III. Rio de Janeiro: Forense Universitária, 2009. p. 53.

71 FOUCAULT, Michel. A linguagem ao infinito. In: Estética: literatura e pintura, música e cinema. Ditos e escritos III. Rio de Janeiro: Forense Universitária, 2009. p. 53.

72 FOUCAULT, Michel. A linguagem ao infinito. In: . Estética: literatura e pintura, música e cinema. Ditos e escritos III. Rio de Janeiro: Forense Universitária, 2009. p. 57.

73 (1964).

74 "Uma é a figura do interdito, da linguagem no limite, do escritor enclausurado. A outra, ao contrário, é o espaço dos livros que se acumulam, que se encostam, uns nos outros, cada um tendo apenas a existência ameiada que o recorta e repete infinitamente no céu se todos os livros" (FOUCAUL, apud MACHADO, 2005, p. 144).

75 FOUCAULT, Michel. Linguagem e literatura. In: MACHADO, Roberto. Foucault, a filosofia e a literatura. Rio de Janeiro: Jorge Zahar Ed.,2005. p. 144. 
explicar a modificação que se processou na literatura ao substituir a Retórica pela Biblioteca: não mais o estabelecimento de uma ponte entre duas palavras, a indicação de uma palavra infinita para além da palavra finita, mas a "sustentação ao infinito das linguagens fragmentares"76, palavra infinita nas dobras de si mesma: um livro infinito nas malhas da intertextualidade. Assim, pelo viés dessas duas direçóes, aparece um dos aspectos do que Foucault, em sua ontologia da literatura, denomina "o ser da linguagem" da literatura moderna, que nas palavras de Roberto Machado "é a repetição, no sentido preciso de a linguagem literária manifestar fundamentalmente o poder de falar da linguagem, o ser das palavras, a linguagem em seu ser" ${ }^{77}$. Segundo o crítico de Foucault:

O ser da linguagem da literatura moderna aparece quando desaparece essa linguagem primeira, absoluta, imediata, mas, ao mesmo tempo, muda, oculta - a Palavra de Deus, a Verdade, o Modelo - que toda obra de linguagem deve restituir, retraduzir, repetir, representar, e a linguagem, entâo, se volta para uma linguagem anterior - o já dito, o rumor, o murmúrio de tudo o que foi pronunciado, as palavras acumuladas na história - com o objetivo principal de repeti-las, através de um movimento de destruição das palavras que libera outras, incessantemente, indefinidamente, infinitamente ${ }^{78}$.

Mas além da repetição há outro aspecto que atravessa "o ser da linguagem” foucaultiano, sem deixar de conectar-se com o ponto já mencionado. Em "O pensamento do exterior"79, texto escrito sobre Blanchot, Foucault afirma que "o ser da linguagem só aparece para si mesmo com o desaparecimento do sujeito" ${ }^{80}$ porque, de acordo com ele, "o acontecimento que fez nascer o

76 FOUCAULT, Michel. A linguagem ao infinito. In: Estética: literatura e pintura, música e cinema. Ditos e escritos III. Rio de Janeiro: Forense Universitária, 2009. p. 58.

77 MACHADO, Roberto. Foucault, a filosofia e a literatura. Rio de Janeiro: Jorge Zahar Ed.,2005. p. 110.

78 MACHADO, Roberto. Foucault, a filosofia e a literatura. Rio de Janeiro: Jorge Zahar Ed.,2005. p. 110.

79 (1966).

80 FOUCAULT, Michel. O pensamento do exterior. In: Estética: literatura e pintura, música e cinema. Ditos e escritos III. Rio de Janeiro: Forense Universitária, 2009. p. 222. 
que no sentido estrito se entende por 'literatura' só é da ordem da interiorização em uma abordagem superficial; trata-se muito mais de uma passagem para fora" ${ }^{\prime 1}$. Na leitura que faz desse conceito blanchotiano que, como vimos, está associado à insurgência do neutro na literatura, a dissolução do sujeito na experiência da escrita que ele propóe é ponto de entrada para Foucault, pois o desaparecimento do "eu" marca a entrada no murmúrio da linguagem, no qual o ser da palavra emerge anônimo e em direção ao vazio deixado, para pensar no limite dessa ausência o impensado, fluxo infinito onde as certezas se perdem.

É na sentença do "eu falo" que ele se apoia para explicar a passagem ao ele, relação impessoal e neutra que a ficção moderna instaura, abalando a garantia do cogito. Em contraposição ao "eu penso" cartesiano, que conduzia à "certeza indubitável do Eu e de sua existência" "2 , o "eu falo" "recua, dispersa, apaga essa existência e dela só deixa aparecer o lugar vazio" 83 . Segundo o filósofo em questão, "a fala da fala nos leva à literatura, mas também talvez a outros caminhos, a esse exterior onde desaparece o sujeito que fala" ${ }^{84}$, pois a dobra que se produz quando a linguagem se abre em torno de si mesma não tem relação com o sujeito, mas com o pensamento do fora: experiência limite na própria palavra. Na proposta foucaultiana, "falar" é tomado em sua transitividade como verbo intransitivo, que se sustenta sem a necessidade de um complemento de qualquer espécie. Nesse sentido, funciona para iluminar a relação neutra, conforme Blanchot a entende, pois anula não apenas o sujeito, mas também o objeto, já que a soberania do "eu falo" reside no fato de que:

nada pode limitá-la - nem aquele a quem ela se dirige, nem a verdade do que ela diz, nem os valores ou os sistemas representativos que ela utiliza: em suma, não é mais discurso e

81 FOUCAULT, Michel. O pensamento do exterior. In: Estética: literatura e pintura, música e cinema. Ditos e escritos III. Rio de Janeiro: Forense Universitária, 2009. p. 221.

82 FOUCAULT, Michel. O pensamento do exterior. In: Estética: literatura e pintura, música e cinema. Ditos e escritos III. Rio de Janeiro: Forense Universitária, 2009. p. 221.

83 FOUCAULT, Michel. O pensamento do exterior. In: Estética: literatura e pintura, música e cinema. Ditos e escritos III. Rio de Janeiro: Forense Universitária, 2009. p. 221.

84 FOUCAULT, Michel. O pensamento do exterior. In: Estética: literatura e pintura, música e cinema. Ditos e escritos III. Rio de Janeiro: Forense Universitária, 2009. p. 221. 
comunicação de um sentido, mas exposição da linguagem em seu ser bruto, pura exterioridade manifesta ${ }^{85}$.

Assim, diferente do "eu minto" que abalou outrora a verdade grega e nos explica o autor, o "eu falo" "põe à prova toda a ficção moderna"" ${ }^{\text {, }}$ pois neste enunciado tanto o objeto quanto o sujeito faltam, dissolvendo a oposição verdade/mentira que figurava na primeira sentença. A narrativa enquanto narrativa que se afirma como fala da fala não precisa de comprovaçáo, ao passo que assume em seu próprio enunciado a impossibilidade de se apresentar como reflexo do mundo, assim como a inviabilidade de estar vinculada à reflexão de uma consciência, pois o que emerge aqui é a linguagem em sua nudez de palavra já vazia, destituída da presença que enuncia; em uma busca contínua escavada em si mesma, para lá do conteúdo, nas margens errantes de seu fora; dobra na obra.

O ser da linguagem, que implica a dissolução do sujeito e seu lançar-se no pensamento do exterior, onde o murmúrio infinito faz a linguagem vagar nômade no deserto que ele abre, é aqui novamente relacionado a Sade e Hölderlin, os quais, para o referido pensador francês, foram os precursores dessa experiência que configura a literatura moderna. No entanto, ele acrescenta que essa brecha aberta por eles "reaparece na segunda metade do século XIX e no próprio âmago da linguagem, que se tornou, embora nossa cultura busque sempre nela se refletir como se ela detivesse o segredo de sua interioridade, o próprio brilho do exterior" ${ }^{87}$. É passando por Nietzsche, Mallarmé, Artaud, Bataille e Klossowski que chega a Blanchot, estrela de seu texto e autor que supóe ser não apenas uma testemunha desse pensamento que dispersa o sujeito, mas também aquele que o constrói em sua própria escrita. Das análises acerca da ficção ${ }^{88}$ deste surge o principal ponto

85 FOUCAULT, Michel. O pensamento do exterior. In: Estética: literatura e pintura, música e cinema. Ditos e escritos III. Rio de Janeiro: Forense Universitária, 2009. p. 220.

86 FOUCAULT, Michel. O pensamento do exterior. In: Estética: literatura e pintura, música e cinema. Ditos e escritos III. Rio de Janeiro: Forense Universitária, 2009. p. 219.

87 FOUCAULT, Michel. O pensamento do exterior. In: Estética: literatura e pintura, música e cinema. Ditos e escritos III. Rio de Janeiro: Forense Universitária, 2009. p. 223.

88 Como, de acordo com Foucault, “a distinção entre 'romances', 'narrativas' e críticas' não cessa de se atenuar em Blanchot” (FOUCAULT, 2009, p. 226), suas análises acerca da ficção blanchotiana podem (e são, inevitavelmente) estendidas à sua reflexão crítica. 
de contato entre ambos ${ }^{89}:$ a fragmentação e a dispersão da unidade subjetiva na experiência da linguagem, pois o que Foucault enfatiza, em sua leitura sobre Blanchot, é o aparecimento de uma "linguagem que não é falada por ninguém: qualquer sujeito delineia aí uma dobra gramatical" ${ }^{\prime 0}$. No âmbito desse pensamento esboçado pelo viés do prisma blanchotiano, que, como vimos, foi também iluminado por Deleuze, Foucault se coloca afirmando que "o ser da linguagem é o visível apagamento daquele que fala" da linguagem da literatura moderna não é apenas reduplicação; como afirma Machado, ele é

também elisão do sujeito, da alma, da interioridade, da consciência, do vivido, da reflexão, da dialética, do tempo, da memória... No momento em que a linguagem escapa da representação clássica e é tematizada como significação na modernidade, a palavra literária se desenvolve, se reduplica a partir de si própria, não como interiorização, psicologização, mas como exteriorização, passagem para fora, afastamento, distanciamento, diferenciação, fratura, dispersão com relação ao sujeito, que ela apaga, anula, exclui, despossui, fazendo aparecer o espaço vazio: o espaço de uma linguagem neutra, anônima ${ }^{92}$.

\section{O estatuto do autor}

A discussão acerca do aparecimento dessa "linguagem neutra, anônima” de que nos fala o crítico de Foucault citado acima, e na qual o sujeito se dilui na experiência da escrita, inevitavelmente aponta para uma questão com a qual se relaciona intimamente: a morte do autor, célebre frase com a qual Ro-

89 Conforme aponta Tatiana Salem Levy "quando Michel Foucault faz uma leitura da questão do fora a partir dos textos de Blanchot, seu principal foco se direciona à fragmentaçáo da unidade subjetiva” (2011, p. 57).

90 FOUCAULT, Michel. O pensamento do exterior. In: Estética: literatura e pintura, música e cinema. Ditos e escritos III. Rio de Janeiro: Forense Universitária, 2009. p. 240.

91 FOUCAULT, Michel. O pensamento do exterior. In: Estética: literatura e pintura, música e cinema. Ditos e escritos III. Rio de Janeiro: Forense Universitária, 2009. p. 240.

92 MACHADO, Roberto. Foucault, a filosofia e a literatura. Rio de Janeiro: Jorge Zahar Ed.,2005. p. 115. 
land Barthes fecha seu texto homônimo. A sentença dessa morte é proferida porque, próximo do pensamento blanchotiano, segundo o qual "escrever é quebrar o vínculo que une a palavra ao eu" ${ }^{3}$, Barthes indica que "a escritura é a destruição de toda voz, de toda origem. A escritura é esse neutro, esse composto, esse oblíquo aonde foge o nosso sujeito, o branco-e-preto aonde vem se perder toda identidade, a começar pela do corpo que escreve" ${ }^{94}$. Embora ele acredite que isso foi sempre assim, reconhece que a forma como o autor foi compreendido varia diacronicamente, e segue variando sincronicamente. Veremos. Enquanto nas sociedades etnográficas um mediador (xamã ou recitador) enunciava, quem fala na sociedade moderna é o gênio, uma das resultantes do culto ao indivíduo. A partir disso, o reinado do Autor, que então se afirma, prolonga-se e se ramifica:

o autor reina ainda nos manuais de história literária, nas biografias de escritores, nas entrevistas dos periódicos, e na própria consciência dos literatos, ciosos por juntar, graças ao seu diário íntimo, a pessoa e a obra; a imagem da literatura que se pode encontrar na cultura corrente está tiranicamente centralizada no autor, sua pessoa, sua história, seus gostos, suas paixōes ${ }^{95}$.

E, além disso, "a crítica, consiste ainda, o mais das vezes" 96 em buscar a explicação da obra no seu produtor. Porém, o quanto suas observações perduram atualmente não nos compete detectar, mas sim o abalo desta categoria, notado por Barthes ainda em 1968, ao mencionar que "apesar de o império do Autor ser ainda muito poderoso [...] é sabido que há muito certos escritores vêm tentando abalá-1o ${ }^{97 "}$. Ao mencionar autores e movimentos importantes nessa alteração e que se configuraram como reação à demasiada importância dada ao autor, entre os quais consta Mallarmé e o Surrealismo, Barthes observa que "o afastamento do Autor [...] não é apenas

93 BLANCHOT, Maurice. O espaço literário. Rio de Janeiro: Rocco, 2011, p. 17.

94 BARTHES, Roland. O rumor da língua. São Paulo: Editora brasiliense, 1984, p. 65.

95 BARTHES, Roland. O rumor da lingua. São Paulo: Editora brasiliense, 1984, p. 66.

96 BARTHES, Roland. O rumor da lingua. São Paulo: Editora brasiliense, 1984, p. 66.

97 BARTHES, Roland. O rumor da lingua. São Paulo: Editora brasiliense, 1984, p. 66. 
um fato histórico ou um ato de escritura: ele transforma radicalmente o texto moderno"98. Nesse sentido, sua consideração coloca-se em consonância com as ideias de Blanchot, Foucault e Deleuze, para os quais a literatura moderna implica essa passagem do eu ao ele, essa ruptura com aquele que escreve em proveito da experiência da escrita: "o texto doravante se faz e se lê de tal forma que nele, em todos os níveis, ausenta-se o autor" "99. Além disso, a concepção de escrita como uma rede de conexóes, que aparece na figura da biblioteca foucaultiana com a repetição contínua que ela sugere, também é focalizada por Barthes, que afirma:

sabemos agora que um texto náo é feito de uma linha de palavras a produzir um sentido único [...] mas um espaço de dimensóes múltiplas, onde se casam e se contestam escrituras variadas, das quais nenhuma é original; o texto é um tecido de citaçôes, saídas dos mil focos da cultura ${ }^{100}$.

É a partir dessa consideração que emerge o escriptor barthesiano, em detrimento da figura do autor clássico, ou seja, aquele que já "não possui mais em si paixōes, humores, sentimentos, impressões, mas esse imenso dicionário de onde retira uma escritura que não pode ter parada"101. Sua consideração, que à primeira vista pode parecer um tanto estruturalista, em especial se nos atentarmos ao termo dicionário, não perde a conexão com os autores aqui trabalhados, já que o vocábulo poderia, sem perda de sentido, ser substituído por murmúrio, pois aqui não é a palavra imóvel que conta, mas a palavra viva em seu fluxo de possibilidades infinitas. De qualquer forma, pensar a categoria do autor também não deixa de ter sua marca estrutural. No entanto, o que importa é notar esse afastamento daquele que escreve; a entrada em uma fala neutra, o movimento de busca escavado no ser da linguagem, o devir ele que a literatura moderna assume. E o fechamento que a crítica centrada no autor impele ao texto, residindo nisto a necessidade que Barthes vê em anunciar sua morte, pois "uma vez afastado o Autor, a preten-

\footnotetext{
98 BARTHES, Roland. O rumor da língua. São Paulo: Editora brasiliense, 1984, p. 68.

99 BARTHES, Roland. O rumor da língua. São Paulo: Editora brasiliense, 1984, p. 68.

${ }^{100}$ BARTHES, Roland. O rumor da língua. São Paulo: Editora brasiliense, 1984, p. 68-69.

${ }^{101}$ BARTHES, Roland. O rumor da língua. São Paulo: Editora brasiliense, 1984, p. 69.
} 
são de 'decifrar' um texto se torna totalmente inútil”'102. Para ele,

na escritura múltipla, com efeito, tudo está para ser deslindado, mas nada para ser decifrado; a estrutura pode ser seguida, "desfiada" (como se diz de uma malha de meia que escapa) em todas as suas retomadas e em todos os seus estágios, mas não há fundo; a escritura propóe sentido sem parar, mas é para evaporá-lo: ela procede a uma isençáo sistemática do sentido. Por isso mesmo, a literatura (seria melhor passar-se a dizer a escritura), recusando designar ao texto (e ao mundo como texto) um "segredo", isto é, um sentido último, libera uma atividade a que se poderia chamar contraideológica, propriamente revolucionária, pois a recusa de parar o sentido é finalmente a recusa de Deus e de suas hipóstases: a razão, a ciência, a lei ${ }^{103}$.

A passagem pela estrutura em direção à abertura de um espaço além desta, onde os limites do dito se pluralizam alargando-se, ao evitar o fechamento do sentido, permite a Barthes observar o caráter transgressivo da literatura, que, ao recusar o sentido, como ele menciona, recusa o discurso corrente e sua palavra de ordem. Essa literatura que nega a função de agir diretamente sobre o mundo, mas que também não se encerra em si mesma é uma escrita neutra, mas não incomunicável, sendo por isso que, para Barthes, o leitor tem um papel fundamental: é quando o autor morre que ele nasce, porque "o leitor é o espaço mesmo onde se inscrevem, sem que nenhuma se perca, todas as citações de que é feita uma escritura" ${ }^{104}$. Mas também aqui ele não é um sujeito: "o leitor é um homem sem história, sem biografia, sem psicologia; ele é apenas esse alguém que mantém reunidos em um único campo todos os traços de que é constituído o escrito" ${ }^{105}$.

${ }^{102}$ BARTHES, Roland. O rumor da língua. São Paulo: Editora brasiliense, 1984, p. 69, grifo do autor.

${ }^{103}$ BARTHES, Roland. O rumor da língua. São Paulo: Editora brasiliense, 1984, p. 69-70, grifos do autor.

${ }^{104}$ BARTHES, Roland. O rumor da lingua. São Paulo: Editora brasiliense, 1984, p. 70.

${ }^{105}$ BARTHES, Roland. O rumor da língua. São Paulo: Editora brasiliense, 1984, p. 70, grifo do autor. 
Quando Barthes assassina o autor é contra a psicologizaçấo da obra que se posiciona, o que significa que ele não está negando a existência de um sujeito empírico que a produz. No entanto, não há ressalvas sobre isso no seu texto, ou seja, ele não se propóe a diferenciar explicitamente o autor enquanto indivíduo real do autor como funçáo, o que encontraremos na conferência de Foucault intitulada "O que é um autor?" 106 e que gira não apenas em torno dessa diferenciação, mas também, e principalmente, do mapeamento dos espaços onde essa categoria desempenha sua função, já que segundo sua posição "o essencial não é constatar uma vez mais o seu desaparecimento; é preciso descobrir como lugar vazio - ao mesmo tempo indiferente e obrigatório -, os locais onde sua função é exercida" ${ }^{107}$. Por isso, ele observa quatro características do discurso dotado da função autor e que, nas palavras de Agamben em seu ensaio intitulado "O autor como gesto", no qual retoma a conferência foucaultiana, são:

um regime particular de apropriaçáo, que sanciona o direito de autor e, ao mesmo tempo, a possibilidade de distinguir e selecionar os discursos entre textos literários e textos científicos, aos quais correspondem modos diferentes da própria função; a possibilidade de autenticar os textos, constituindo-os em cânone ou, pelo contrário, a possibilidade de certificar o seu caráter apócrifo; a dispersão da função enunciativa simultaneamente em mais sujeitos que ocupam lugares diferentes; e, por fim, a possibilidade de construir uma função transdiscursiva, que constitui o autor para além dos limites de sua obra, como “instaurador da discursividade" 108.

Sobre essa questão não nos deteremos, pois o que importa aqui não é observar como o campo literário se constitui, mas a diferença entre a função autor e o autor empírico, assim como a necessidade de iluminar essa separação;

106 (1969).

${ }^{107}$ FOUCAULT, Michel. O que é um autor? In: Estética: literatura e pintura, música e cinema. Ditos e escritos III. Rio de Janeiro: Forense Universitária, 2009. p. 264.

${ }^{108}$ AGAMBEN, Giorgio. O autor como gesto. In: . Profanaçôes. São Paulo: Boitempo, 2007. p. 56, grifo do autor. 
argumentos apresentados por Foucault, que inaugura sua fala com a citação de Beckett "que importa quem fala, alguém disse que importa quem fala?", para colocar de saída que "nessa indiferença se afirma o princípio ético, talvez o mais fundamental, da escrita contemporânea" ${ }^{109}$. A indiferença que menciona aparece como regra imanente à prática da escrita devido a dois aspectos. De um lado, esta se libertou do tema da expressão, "ela se basta a si mesma, e, por consequência, não está obrigada a forma da interioridade; ela se identifica com sua própria exterioridade desdobrada" ${ }^{110}$. Do outro, metamorfoseou a relação milenar da escrita com a morte: "a obra que tinha o dever de trazer a imortalidade recebeu agora o direito de matar, de ser assassina do seu autor" 111 .

No entanto, embora o apagamento e a morte do autor que observa já tenham sido detectados pela crítica e pela filosofia, como menciona, Foucault acredita que algumas das noçóes utilizadas para destituí-lo de seu trono não se configuram sem problemas: uma delas é a de obra e a outra a de escrita. Em detrimento à relação da obra com o autor, que perdurou por muito tempo, a crítica se propôs a analisar a estrutura da obra. No entanto, "o que é uma obra? O que é, pois essa curiosa unidade que se designa com o nome de obra? De quais elementos ela se compóe? Uma obra não é aquilo que é escrito por aquele que é um autor?" 112 , pergunta Foucault, entre outros questionamentos, para indicar "que é insuficiente afirmar: deixemos o autor e vamos estudar, em si mesma, a obra. A palavra 'obra' e a palavra que ela designa são provavelmente tâo problemáticas quanto a individualidade do autor" 113 . A outra noção, a de escrita, também se torna problemática porque ao invés de revelar a ausência "com sutileza, ela ainda preserva a existência do autor"114, ela "faz subsistir, na

${ }^{109}$ FOUCAULT, Michel. O que é um autor? In: - Estética: literatura e pintura, música e cinema. Ditos e escritos III. Rio de Janeiro: Forense Universitária, 2009. p. 264.

${ }^{110}$ FOUCAULT, Michel. O que é um autor? In: . Estética: literatura e pintura, música e cinema. Ditos e escritos III. Rio de Janeiro: Forense Universitária, 2009. p. 268.

${ }^{111}$ FOUCAULT, Michel. O que é um autor? In: Estética: literatura e pintura, música e cinema. Ditos e escritos III. Rio de Janeiro: Forense Universitária, 2009. p. 269.

${ }^{112}$ FOUCAULT, Michel. O que é um autor? In: - Estética: literatura e pintura, música e cinema. Ditos e escritos III. Rio de Janeiro: Forense Universitária, 2009. p. 269.

${ }^{113}$ FOUCAULT, Michel. O que é um autor? In: - Estética: literatura e pintura, música e cinema. Ditos e escritos III. Rio de Janeiro: Forense Universitária, 2009. p. 270.

${ }^{114}$ FOUCAULT, Michel. O que é um autor? In: . Estética: literatura e pintura, música e cinema. Ditos e escritos III. Rio de Janeiro: Forense Universitária, 2009. p. 270. 
luz obscura da neutralização, o jogo das representaçóes que formaram uma certa imagem do autor" ${ }^{\prime 15}$.

É devido a essas deficiências não resolvidas pela crítica que o referido pensador se posiciona dizendo que "não basta refletir como afirmação vazia que o autor morreu" 116 , é preciso percorrer e sondar os espaços deixados pelo seu desaparecimento. Como afirma Giorgio Agamben, a contradição contida na citação de Beckett utilizada na conferência foucaultiana já indica essa necessidade, pois nela há "alguém que, mesmo continuando anônimo e sem rosto, proferiu o enunciado, alguém sem o qual a tese, que nega a importância de quem fala, náo teria podido ser formulada" 117 . Sendo assim, e com o intuito de analisar "a relação do texto com o autor, a maneira com que o texto aponta para essa figura que lhe é exterior e anterior, pelo menos aparentemente" 118 , Foucault apresenta algumas dificuldades que o uso desse nome suscita. De acordo com ele, "o nome do autor não é [...] um nome próprio como os outros" ${ }^{119}$, pois ele não serve para referir-se a uma pessoa, e sim para desempenhar uma função classificatória. De acordo com Foucault:

o nome do autor não passa, como o nome próprio, do interior de um discurso ao indivíduo real e exterior que o produziu [...] Ele manifesta a ocorrência de um certo conjunto de discurso, e refere-se ao status desse discurso no interior de uma sociedade e de uma cultura [...] Consequentemente, poder-se-ia dizer que há, em uma civilização como a nossa, um certo número de discursos que são providos da função "autor", enquanto

${ }^{115}$ FOUCAULT, Michel. O que é um autor? In: Estética: literatura e pintura, música e cinema. Ditos e escritos III. Rio de Janeiro: Forense Universitária, 2009. p. 271.

${ }^{116}$ FOUCAULT, Michel. O que é um autor? In: - Estética: literatura e pintura, música e cinema. Ditos e escritos III. Rio de Janeiro: Forense Universitária, 2009. p. 271.

117 AGAMBEN, Giorgio. O autor como gesto. In: . Profanaçóes. São Paulo: Boitempo, 2007. p. 55.

118 FOUCAULT, Michel. O que é um autor? In: . Estética: literatura e pintura, música e cinema. Ditos e escritos III. Rio de Janeiro: Forense Universitária, 2009. p. 267.

${ }^{119}$ FOUCAULT, Michel. O que é um autor? In: . Estética: literatura e pintura, música e cinema. Ditos e escritos III. Rio de Janeiro: Forense Universitária, 2009. p. 271. 
outros são dela desprovidos. Uma carta particular pode ter um signatário, ela não tem um autor $[\ldots]^{120}$.

Nesse sentido, "a função-autor aparece como processo de subjetivação mediante o qual um indivíduo é identificado e constituído como autor de um certo corpus de texto"121. Por conseguinte, a crítica não deve buscar nas experiências do autor empírico a interpretação da obra, mas também não pode sustentar-se na consideração de que a obra existe por si mesma, pois a afirmação do desaparecimento do autor na experiência da escrita moderna faz com que essa categoria adquira novas funçóes sociais. A morte do autor não se refere à inexistência de alguém que produz a obra; e sim, à ausência deste escavada na própria obra, conforme indica Agamben: "o autor não está morto, mas pôr-se como autor significa ocupar o lugar de um morto. Existe um sujeito-autor, e, no entanto, ele se atesta unicamente por meio dos sinais de sua ausência" ${ }^{22}$. Mas como entender essa presença-ausência do autor na obra?

Para pensá-la, o filósofo italiano volta-se para outro texto de Foucault: A vida dos homens infames, a partir do qual nota que "exatamente como o infame, o autor está presente no texto apenas em um gesto, que possibilita a expressão na mesma medida em que nela instala um vazio central" ${ }^{123}$. Como o gesto é por ele entendido como aquilo "que continua inexpresso em cada ato de expressáo" ${ }^{124}$, o que parece ser fixado, tanto nos arquivos dessas vidas infames como na obra literária moderna, deixa uma margem aberta, na qual o vazio e o inexpresso vêm vaguear. Nas vidas infames registradas pelo discurso do poder há algo que escorre através do dito; silêncio ou grito que escapa ao retrato no momento em que essas vidas são postas em jogo e ali decididas. A vida infame não pertence nem àqueles que a enunciaram nem aos que foram

${ }^{120}$ FOUCAULT, Michel. O que é um autor? In: Estética: literatura e pintura, música e cinema. Ditos e escritos III. Rio de Janeiro: Forense Universitária, 2009. p. 274.

${ }^{121}$ AGAMBEN, Giorgio. O autor como gesto. In: - Profanaçóes. São Paulo: Boitempo, 2007. p. 57.

${ }^{122}$ AGAMBEN, Giorgio. O autor como gesto. In: 2007. p. 58.

${ }^{123}$ AGAMBEN, Giorgio. O autor como gesto. In: Profanações. São Paulo: Boitempo, 2007. p. 59.

${ }^{124}$ AGAMBEN, Giorgio. O autor como gesto. In: Profanações. São Paulo: Boitempo, 2007. p. 59. . Profanaçóes. São Paulo: Boitempo, 
enunciados porque "ela é apenas jogada, nunca possuída, nunca representada, nunca dita - por isso, ela é o lugar possível, mas vazio, de uma ética, de uma forma-de-vida" ${ }^{125}$. A literatura também seria o lugar dessa ética, posto que, para Agamben, o autor não pode ser encontrado na obra; ao contrário, ele:

marca o ponto em que uma vida foi jogada na obra. Jogada, não expressa; jogada, não realizada. Por isso, o autor nada pode fazer além de continuar, na obra, não realizado e não dito. Ele é o ilegível que torna possível a leitura, o vazio lendário de que procedem a escritura e o discurso ${ }^{126}$.

O exemplo literário que nos dá, para esclarecer suas consideraçóes, não podia ser melhor. O caráter polifônico dos romances de Dostoiévski, conforme sugeriu Bakhtin, permite a Agamben observar a independência de Nastasja em $O$ idiota, personagem que, ao aceitar entrar no jogo da sociedade, também coloca em jogo sua vida e age além dos cálculos. É a partir do que transborda de suas atitudes, do que não pode ser apreendido e parece sem sentido, próximo ao delírio, que Agamben nos explica a ética a que se refere, e que não é a vida "que simplesmente se submete à lei moral, mas a que aceita, irrevogavelmente e sem reservas, pôr-se em jogo nos seus gestos"127. Uma linha de vida que corre na literatura, como afirma Deleuze.

\title{
DEVENIR-ÉL: LO NEUTRO EN LA LITERATURA
}

\begin{abstract}
RESUMEN
$\mathrm{Al}$ reconocer que la despersonalización del sujeto en la experiencia de la escrita es para algunos pensadores un aspecto crucial de la literatura moderna, el presente trabajo visa una aproximación de las propuestas de Blanchot,
\end{abstract}

${ }^{125}$ AGAMBEN, Giorgio. O autor como gesto. In: 2007. p. 60.

${ }^{126}$ AGAMBEN, Giorgio. O autor como gesto. In: 2007. p. 61.

${ }^{127}$ AGAMBEN, Giorgio. O autor como gesto. In: 2007. p. 61.

. Profanações. São Paulo: Boitempo, . Profanações. São Paulo: Boitempo, . Profanações. São Paulo: Boitempo, 
Foucault, Deleuze, Guattari, Barthes y Agamben, con el intuito de observar el carácter transgresivo que hay por tras del pasaje del yo al él, indicada por ellos.

PALABRAS-CLAVE: Literatura moderna; Neutro; Devenir.

Recebido em: 27/06/2012

Aprovado em: 17/01/2013 